\title{
New mineralogical data on platinum-group minerals from the Río Santiago alluvial placer, Esmeraldas province, Ecuador
}

\author{
Nuevos datos mineralógicos de los minerales del grupo del platino en los placeres aluviales del \\ Río Santiago, provincia de Esmeraldas, Ecuador
}

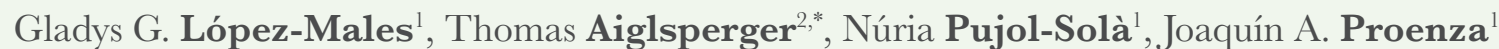

\begin{abstract}
Department de Mineralogia, Petrologia i Geologia Aplicada, Facultat de Ciències de la Terra, Universitat de Barcelona (UB), Martí i Franquès s/n, 08028, Barcelona, Spain.

${ }^{2}$ Luleå University of Technology, Department of Civil Engineering and Natural Resources, Division of Geosciences and Environmental Engineering, SE 97187, Luleå, Sweden.

* Corresponding author: (T. Aiglsperger) thomas.aiglsperger@ltu.se
\end{abstract}

\begin{abstract}
Mineralogical studies on platinum-group minerals found in placer deposits from the Río Santiago (Ecuador) are scarce. In this investigation, one sample collected from the Río Santiago alluvial placer was studied via a multi-disciplinary approach, including optical microscopy, scanning electron microscopy, electron microprobe, and Raman spectroscopy. Whole-rock geochemistry data of the sample confirms elevated $\mathrm{Au}$ and platinum-group elements contents and the chondrite-normalized pattern reveals pronounced positive Ir and $\mathrm{Pt}$ anomalies. Free grains of platinum-group minerals were separated via hydroseparation techniques and identified as: i) Pt-Fe alloy $\left(\mathrm{Pt}_{3} \mathrm{Fe}\right)$, ii) tulameenite $\left(\mathrm{Pt}_{2} \mathrm{FeCu}\right)$ and iii) hongshiite $(\mathrm{PtCu})$. The most abundant platinum-group mineral is $\mathrm{Pt}-\mathrm{Fe}$ alloy $(85 \%)$ that occasionally hosts cuprorhodsite $\left(\mathrm{CuRh}_{2} \mathrm{~S}_{4}\right)$ inclusions. Although the primary source remains unknown, the geochemical and mineralogical data suggests that the source of platinum-group minerals in the Río Santiago alluvial placer is a mafic-ultramafic Ural-Alaska type complex. Possible primary sources are the mafic and ultramafic rocks found in the mafic basement of the coastal region and the Western Cordillera (Piñón, San Juan and Pallatanga units), which derive from the Late Cretaceous Caribbean Colombia Oceanic Plateau (CCOP).
\end{abstract}

Keywords: Pt-Fe alloy, Ecuador, PGM, placer deposit, Río Santiago.

\section{RESUMEN}

Los estudios mineralógicos sobre minerales del grupo del platino procedentes de depósitos del tipo placer de Río Santiago (Ecuador) son escasos. Este trabajo presenta un estudio mineralógico detallado de una muestra recogida en el placer aluvial de Río Santiago. Las técnicas usadas incluyen microscopía óptica, microscopia electrónica de barrido, análisis de microsonda electrónica y espectroscopía Raman. La geoquímica de roca total de la muestra estudiada confirma unos valores elevados en oro y en elementos del grupo del platino, y los patrones normalizados a condrito muestran anomalías positivas pronunciadas de Ir y Pt. Se separaron granos de minerales del grupo del platino mediante técnicas de hidroseparación y estos se han identificado como: i) aleación $\mathrm{Pt}-\mathrm{Fe}\left(\mathrm{Pt}_{3} \mathrm{Fe}\right)$, ii) tulameenita ( $\mathrm{Pt} \mathrm{FeCu}_{2}$ y iii) hongshiita (PtCu). La fase más abundante es la aleación Pt-Fe (85\%), con inclusiones micrométricas de cuprorhodsita $\left(\mathrm{CuRh} \mathrm{R}_{2} \mathrm{~S}_{4}\right)$ en algunos granos. Aunque la fuente primaria aún se desconoce, los datos geoquímicos y mineralógicos sugieren que los minerales del grupo del platino en el placer aluvial de Río Santiago derivan del desmantelamiento erosivo de un complejo máfico-ultramáfico de tipo Ural-Alaska. Las fuentes primarias podrian estar relacionadas con las rocas máficas-ultramáficas descritas en las unidades del basamento máfico de la Cordillera Occidental y la Costa de Ecuador (Piñón, San Juan y Pallatanga). Estas unidades han sido interpretadas como fragmentos del plateau oceánico del Caribe y Colombia (CCOP) de edad cretácico superior.

Palabras clave: aleaciones Pt-Fe, Ecuador, EGP, depósito aluvial, Río Santiago. 


\section{Introduction}

Platinum-group mineral (PGM) alluvial placer ore deposits are usually associated with the weathering of concentrically-zoned ultramafic intrusions at convergent margin settings (i.e. in Alaska and the Urals; Tolstykh et al., 2002). In general, such so-called Ural-Alaska type complexes are characterized by a dunitic core hosting the primary PGM mineralization that migrates outward into wehrlite, clinopyroxenite and gabbroic lithologies (Krause, 2008 and references therein). PGM placer ore deposits were the dominant source of platinum-group elements (PGE) from the mid-18 ${ }^{\text {th }}$ century until the early $20^{\text {th }}$ century (Cabri et al., 1996).

The first description of silvery PGM grains of 'platina' (meaning 'little silver' in Spanish) was provided by Spanish conquistadors on PGM found in a river in the Chocó region of the Viceroyalty of New Granada on the Pacific coast of today's Colombia and/or Ecuador (Juan and Ulloa, 1748; Gervilla et al., 2020). Placer deposits from South America were the only source of PGM until the discovery of similar deposits in the Russian Ural Mountains in 1825 (Mertie, 1969). The first detailed investigation on PGM composition and origin from placer deposits in Ecuador originates from Weiser and Schmidt-Thomé (1993), who studied the Río Santiago alluvial placer in the Esmeraldas province. These authors identified Pt-Fe alloy as the main PGM in the placer deposit and concluded that the source of the primary PGE mineralization is most likely associated with an undiscovered Ural-Alaska type complex.

The present study aims to contribute to the still open questions of provenance and geological history of the alluvial noble metal concentration found in the Río Santiago river by providing new geochemical and mineralogical data of PGM from the study area. The study aims (1) to determine the different PGM phases, (2) to investigate their mineral inclusions and (3) to discuss a possible primary source for the PGM found in sediments of the Río Santiago.

\section{Geological setting}

Ecuador consists of six major geological units based on the time of their formation (Figure 1). These six geological units can be divided geographically into five morphotectonic regions (Vallejo et al., 2009; Figure 1): (1) the coastal region, comprising a mafic crystalline basement covered by fore-arc deposits; (2) the Western Cordillera, which consists of mafic and intermediate volcanic and intrusive rocks that are tectonically interrupted by turbiditic deposits of Late Cretaceous to Oligocene age (Vallejo et al., 2009); (3) the inter-Andean structure, which is located between the Western Cordillera and the Eastern Cordillera and comprises Pliocene to Pleistocene volcanic deposits (Winkler et al., 2005); (4) the Eastern Cordillera, which consists of Paleozoic metamorphic rocks and Mesozoic granitoids (Aspden and Litherland, 1992); and (5) the Orient Basin, which is considered a fore-arc basin that developed after the formation of the Eastern Cordillera (Martin-Gombojav and Winkler, 2008).

The Río Santiago area is located in the Esmeraldas province, within the coastal region in north-western Ecuador (Figure 1). The basement of the Esmeraldas basin includes the San Juan, Pallatanga, Piñón, Colorado, and Naranjal formations, all of them Cretaceous in age (Vallejo et al., 2009 and references therein). The Piñón Fm. (88.0 \pm 1.6 Ma; Luzieux et al., 2006) is formed by volcanic rocks that occur in the Businga Dome and in the east of the Toisán Cordillera (Figure 2). Pallatanga and San Juan units consist of Late Cretaceous basalts, gabbroic and ultramafic rocks (Spikings et al., 2001; Kerr et al., 2002; Mamberti et al., 2004). The San Juan ultramafic-mafic assemblage has been dated at $87.10 \pm 1.66 \mathrm{Ma}$ (SHRIMP U-Pb zircon age; Vallejo, 2007). The Piñón, San Lorenzo and Pallatanga units represent the mafic basement of the coastal region and the Western Cordillera and are interpreted to be derived from the Caribbean-Colombian Oceanic Plateau (Kerr et al., 2002; Luzieux et al., 2006; Vallejo et al., 2009 and references therein). 


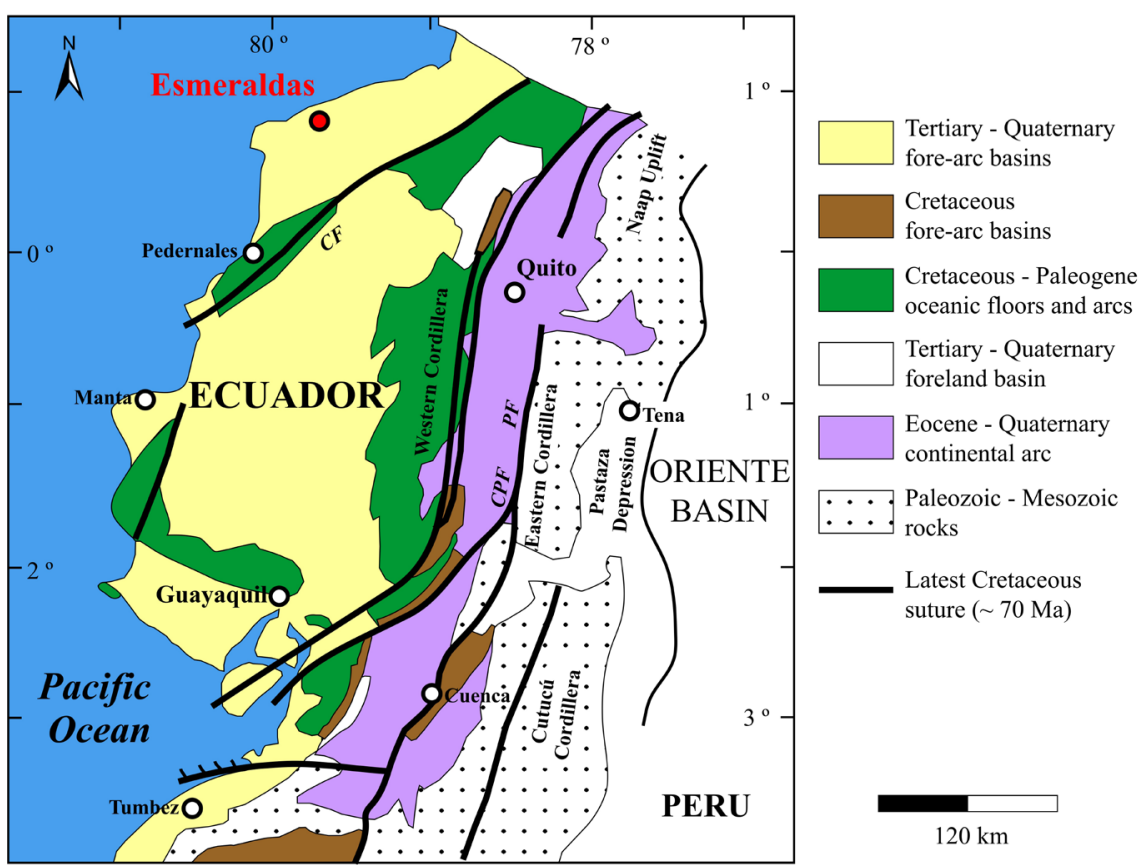

Figure 1 Geological map of Ecuador, modified from Mamberti et al. (2004). Abbreviations: PF: Peltetec Fault, CPF: Calacalí - Pallatanga Fault, CTF: Chimbo - Toachi Fault, CF: Canande Fault.
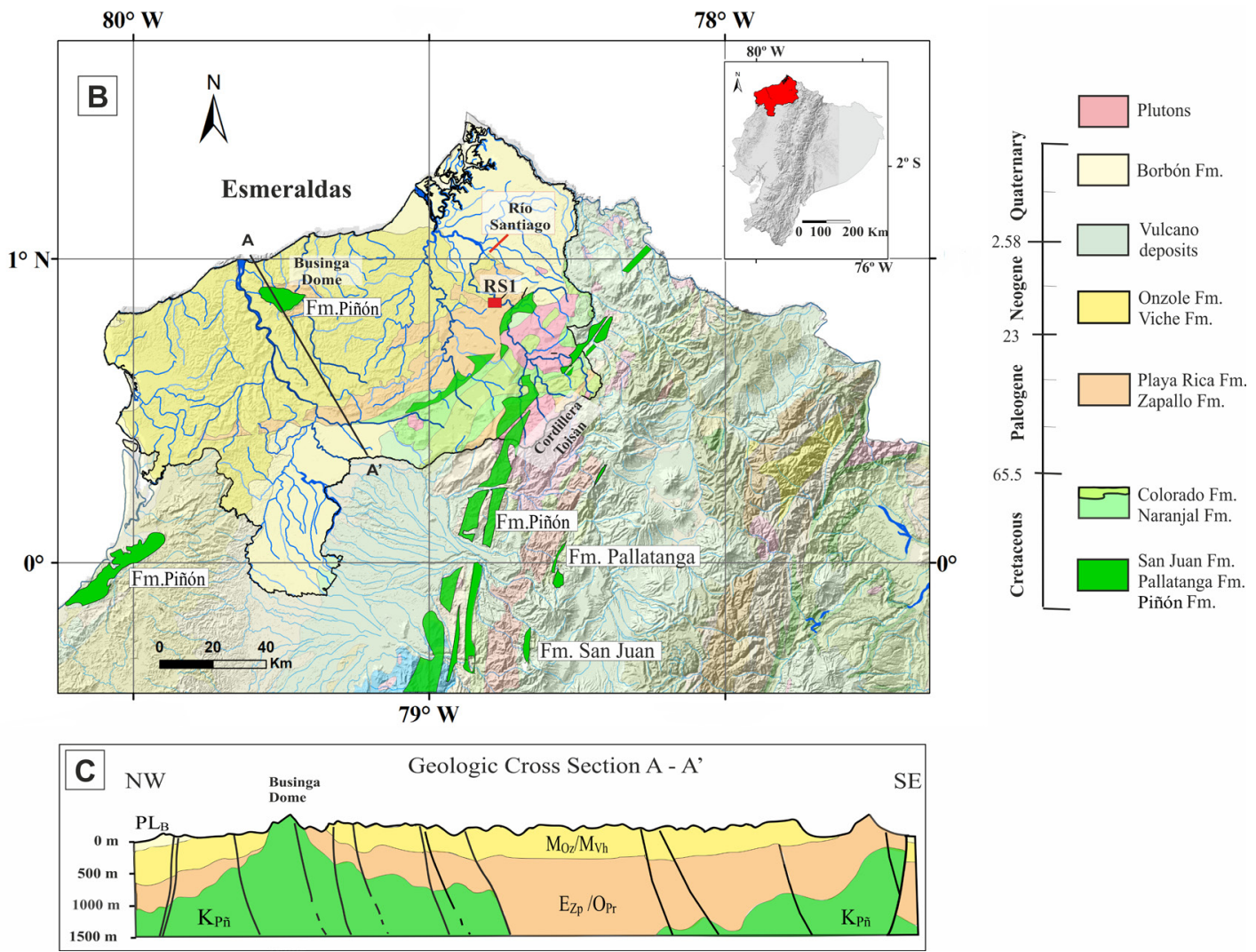

Figure 2 A) Geological map of Esmeraldas province (modified from INIGEMM and Ministerio de Energía y Minas, Dirección Nacional de Geología, 2001), B) Section A - A' (NW - SE), modified from “Mapa Geológico de la Margen Costanera Ecuatoriana” (Reyes and Michaud, 2012). Abbreviations: KPñ: Piñón Formation, EZp: Zapallo Formation, OPr: Playa Rica Formation, MOz: Onzole Formation, MVh: Vilche Formation, and PLB: Borbón Formation. 
The Naranjal Fm. consists of island arc rocks, mainly basaltic and andesitic lavas. The Colorado Fm. overlays the Naranjal Fm. and consists of sandstones, siltstones and conglomerates (Reyes and Michaud, 2012). The Paleogene formations overlaying the Cretaceous basement include (Vallejo et al., 2009): (1) the Macuchi Fm., which consists of pillow lavas, andesites, basaltic breccias, and volcano-clastic deposits; (2) the Zapallo Fm., composed of a medium to fine grained clastic sequence, with a thickness greater than $500 \mathrm{~m}$, and (3) the Playa Rica Fm., including volcano-clastic deposits formed by green to gray sandstones interbedded with siltstones and shales, cropping out in the Businga Dome, overlaying the Piñón Fm. (Figure 2B). Quaternary materials from the Borbón $\mathrm{Fm}$. consist of coarse massive sandstones.

\section{Materials and methods}

The studied sample (RS1) was taken by artisanal miners from the so-called Playa de Oro community in the Río Santiago alluvial terraces $\left(0.856317^{\circ} \mathrm{N}\right.$ / -78.901197 E). The sample consisted of black sand that was pre-concentrated by on-site panning to recover heavy minerals (Figure 3A). The final panning concentrate (311 g; Figure 3B) was sent to the University of Barcelona for geochemical and mineralogical studies.
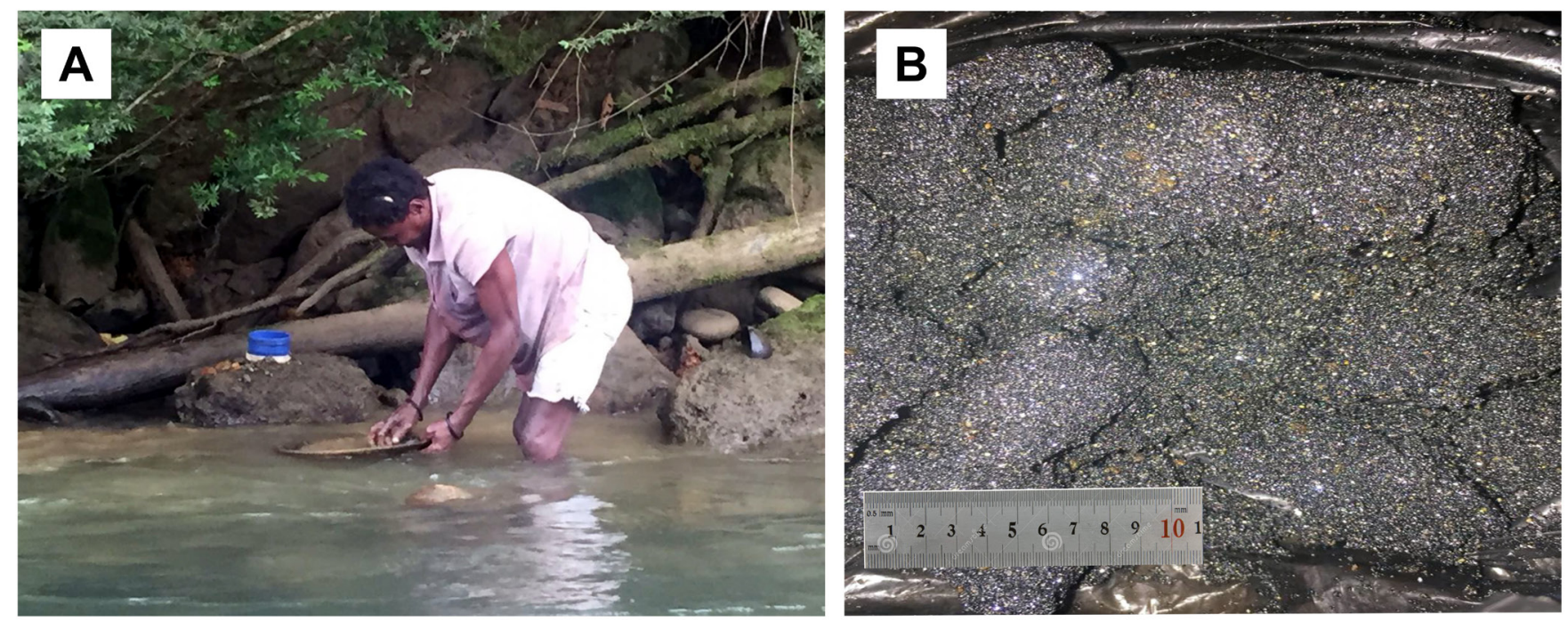

Figure 3 A) Sampling and pre-concentration on-site of heavy minerals at Río Santiago; B) Sample RS1 that was sent to the University of Barcelona.

\subsection{PGE AND Au GONTENT OF THE PANNING GONGENTRATE}

Geochemical analyses were obtained at Genalysis Ltd. (Maddington, Western Australia) by inductively coupled plasma mass spectrometry (ICP-MS) using a $50 \mathrm{~g}$ sample aliquot. The detection limits are $1 \mathrm{ppb}$ for Os, Ir, Ru, Rh, Pt and Pd and 2 ppb for $\mathrm{Au}$. The detailed method is described in Gervilla et al. (2005).

\subsection{X-RAY POWDER DIFFRACTION (XRD)}

XRD analyses were performed at Centres Científics i Tecnològics from the University of Barcelona (CCiT-UB) using a diffractometer PANalytical X'Pert PRO MPD Alphal with geometry $\theta / 2 \theta$ Bragg-Brentano, a radiation $\mathrm{Kal}$ of $\mathrm{Cu}(\lambda=1.5406 \AA)$, and analytical conditions of $45 \mathrm{kV}$ and $40 \mathrm{~mA}$.

\subsection{HEAVY MINERAL GONGENTRATION}

Laboratory scale heavy mineral concentration was performed after wet-sieving the sample into the grain size fractions (RS1A): $<30 \mu \mathrm{m}, 30-75 \mu \mathrm{m}$, $75-125 \mu \mathrm{m}$ and $>125 \mu \mathrm{m}$. Subsequently the $>125$ $\mu \mathrm{m}$ fraction was dry-sieved to obtain the size fractions (RS1B): 125-180 $\mu \mathrm{m}, 180-250 \mu \mathrm{m}, 250-355$ $\mu \mathrm{m}, 355-400 \mu \mathrm{m}, 400-500 \mu \mathrm{m}, 500-630 \mu \mathrm{m}, 630$ $\mu \mathrm{m}-1 \mathrm{~mm}, 1-2 \mathrm{~mm}$ and $>2 \mathrm{~mm}$. 


\subsubsection{HYDROSEPARATION}

The finer size fractions (RS1A) were processed by hydroseparation (HS) techniques at the HS laboratory in Barcelona (http:/ / www.hslab-barcelona. com). This method simulates natural beach placer deposits using the software-controlled hydroseparator HS-1 1 (http:/ /www.cnt-mp.com), by which heavy minerals are concentrated at the bottom of a glass separation tube due to the combination of a laminar water flow at constant pressure and wave impulses. Final heavy minerals concentrates were mounted as monolayers of free grains at the surface of polished metallic cylinders.

\subsubsection{MAGNETIC SEPARATION}

Magnetic minerals from RS1B were first separated using a hand magnet. Subsequently all fractions $<500 \mu \mathrm{m}$ were individually processed using a Frantz magnetic separator with a slope of $20^{\circ}$ and a tilt of $15^{\circ}$. The electric current intensity varied from 0.05 to $0.1 \mathrm{~A}$, and from 0.1 to $0.4 \mathrm{~A}$, according to the magnetic response of processed minerals. The final non-magnetic concentrates were investigated under a binocular microscope and PGM grains were handpicked and mounted as a monolayer on the surface of a metallic cylinder.

\subsubsection{SCANNING ELECTRON MICROSCOPE (SEM-EDS)}

The monolayers of free grains were first investigated without C-coating by scanning electron microscopy (SEM) using a Quanta 200 FEI XTE 325/D8395 at the CCiT-UB in low vacuum conditions with $1 \mathrm{nA}$ electron beam and accelerating voltage of $20 \mathrm{kV}$. The monolayers were then included in resin blocks and polished.

\subsubsection{RAMAN SPECTROSCOPY}

The inclusions hosted within PGM were investigated with Raman spectroscopy using a HORIBA Jobin Yvon LabRam HR 800 provided with an Olympus BXFM optical microscopy at the CGiT-UB. The Raman spectra were obtained with a $532 \mathrm{~nm}$ laser, with $1 \mu \mathrm{m}$ spot size, $20 \mathrm{~s}$ of exposition and 3 repetitions.

\subsubsection{ELECTRON PROBE MICROANALYZER (EPMA)}

Selected grains were investigated by wavelength-dispersive spectroscopy (WDS) using a JEOL JXA-8230 electron microprobe at the CCiT-UB. The analytical conditions were: accelerating voltage of $20 \mathrm{kV}$, beam current of $51 \mathrm{nA}$ and beam diameter of 1 to $5 \mu \mathrm{m}$ (for inclusions and homogenous bulk areas, respectively). The applied analytical features for specifying the chemical composition of PGM can be found in Aiglsperger et al. (2015).

\section{Results}

\subsection{MINERAL COMPOSITION, PGE AND Au CONTENTS}

The main minerals identified by XRD in the initial concentrate are ilmenite (most abundant), quartz and magnetite. It is important to mention that ilmenite as a major mineral phase was previously observed by Gervilla et al. (2020) in a historic 'platina' sample. High ilmenite abundances seem therefore to be a common feature for alluvial placers from the Colombia-Ecuador coastal zone. Geochemical analyses revealed a total PGE content of $27.5 \mathrm{ppm}$ and $17.3 \mathrm{ppm} \mathrm{Au}$ (Table 1). The chondrite-normalized pattern shows a positive slope from Os to $\mathrm{Au}$ with pronounced negative anomalies for $\mathrm{Ru}$ and $\mathrm{Pd}$ that are responsible for the appearance of strong positive anomalies for Ir and Pt (Figure 4).

\subsection{PGE MINERALOGY}

Thirteen grains of Pt-Fe alloys were discovered and confirmed by EDS analyses. The grain sizes range from $<30 \mu \mathrm{m}$ to $1 \mathrm{~mm}$ (Table 2). The morphology of PGM grains is diverse, including rounded, subrounded, tabular and flattened irregular shapes. Some grains show corrosion features. Three different types of PGE alloys occurring as free grains were analyzed by EPMA and identified based on 


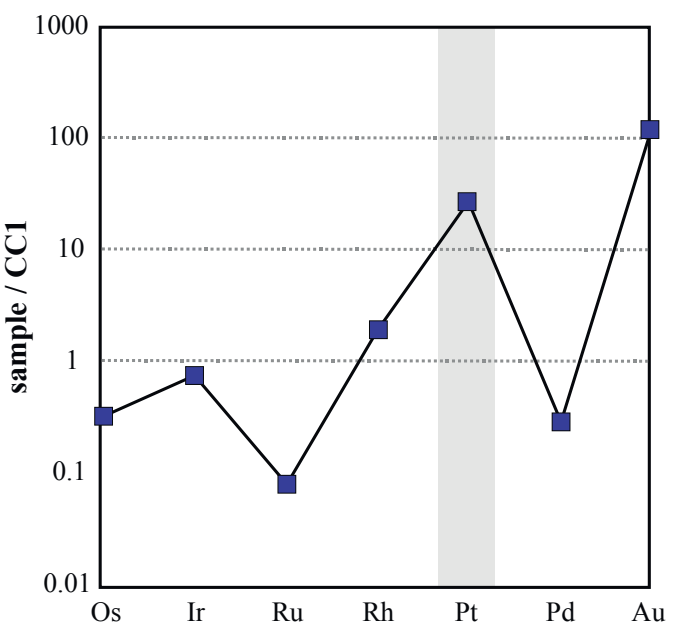

Figure 4 Chondrite-normalized pattern for sample RS1. Normalization values were taken from Naldrett and Duke (1980).

stoichiometry: i) Pt3Fe (Pt-Fe alloy), ii) Pt2FeCu (tulameenite) and iii) $\mathrm{PtCu}$ (hongshiite) (Figure 5). Pt-Fe alloy (1 1 grains) is the most abundant PGM in the studied sample.

\subsubsection{Pt-Fe ALLOY}

Individual grains of $\mathrm{Pt}-\mathrm{Fe}$ alloy have a rather homogenous appearance, without visible exsolutions or rimming (Figure 6). However, the Pt content in the Pt-Fe alloys varies from 65.7 to 79.13 at. $\%$, and the Fe content from 15.74 to 25.48 at. \%. In addition, $\mathrm{Cu}$ is present in all grains and ranges from 0.68 to 6.21 at. $\%$ and $\mathrm{Ni}$ varies from below detection limit (bdl) to 0.43 at. \% (Table 3). Onother PGE present in Pt-Fe alloy are Rh $(0.4-3.57$ at. $\%), \operatorname{Ir}(0.16-4.09$ at. $\%), \mathrm{Os}(\mathrm{bdl}-1.33$ at. $\%)$, and $\mathrm{Pd}(0.31-2.19$ at. \%), whereas $\mathrm{Ru}$ is mostly below detection limit, with a maximum of 1.17 at. $\%$.

Figure 7 shows a comparison of the chemical composition of Pt-Fe alloy identified in the present study and those found by Weiser and SchmidtThomé (1993). The frequency distribution diagram (Figure 8 ) shows that about $70 \%$ of the analyzed spots in our work have Fe contents of 15 - 22 at. $\%$, and about $30 \%$ of the analyzed spots have Fe contents of $23-26$ at. \%. These results can be compared well with those from single grain analyses by Weiser and Schmidt-Thomé (1993; Figure 8). Interestingly, some grains of Pt-Fe alloy have homogenously-distributed high $\mathrm{Cu}$ contents up to 6.2 at. \% (Figure 6E). Other grains show a compositional variation with $\mathrm{Pt}$-rich and $\mathrm{Fe}$-poor zones (Figure 6F). Similar features are well-known in the case of electrum refining in supergene environments due to silver leaching (Knight et al., 1999).

\subsubsection{TULAMEENITE}

One free grain of tulameenite was found in the $<30 \mu \mathrm{m}$ fraction and represents, to the authors' knowledge, the first discovery of this mineral in Ecuador. The subhedral grain is characterized by a homogeneous texture without visible exsolutions (Figures 9A and 9B). The chemical composition of the grain is shown in Table 4. Tulameenite was first described from Alaskan-type intrusions in the Tulameen Complex, British Columbia and from the Urals (Cabri et al., 1973; 1996).

\subsubsection{HONGSHIITE}

Hongshiite was identified as a free grain in the $<30$ $\mu \mathrm{m}$ fraction by EPMA. This is the first description of hongshiite as a free grain from the Río Santiago

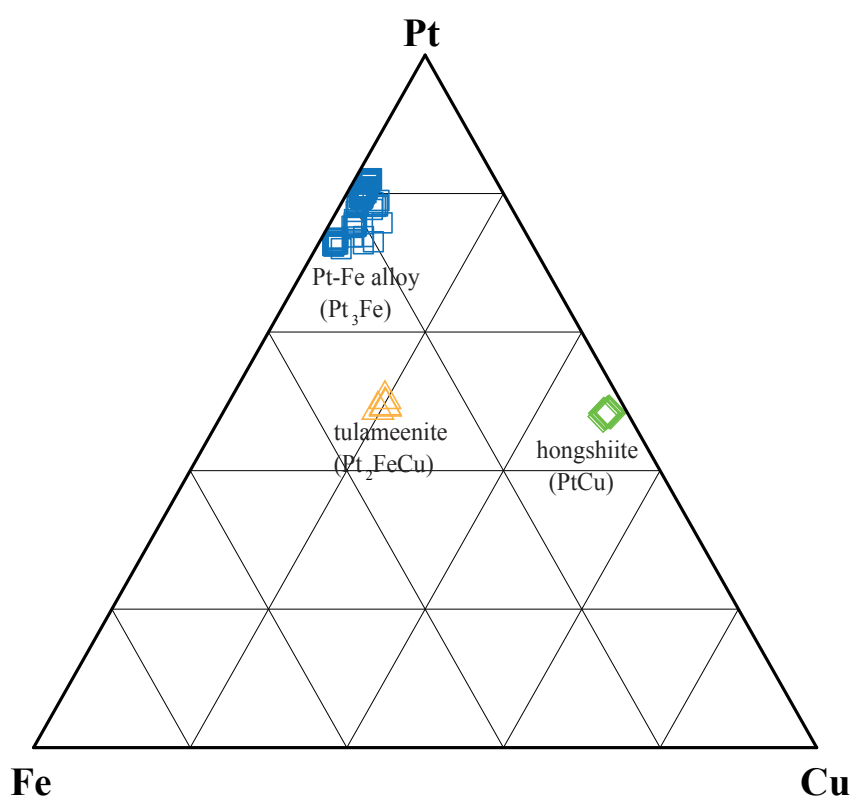

Figure $5 \mathrm{Fe}-\mathrm{Pt}$-Cu diagram showing the chemical composition of PGM that were detected as free grains. 

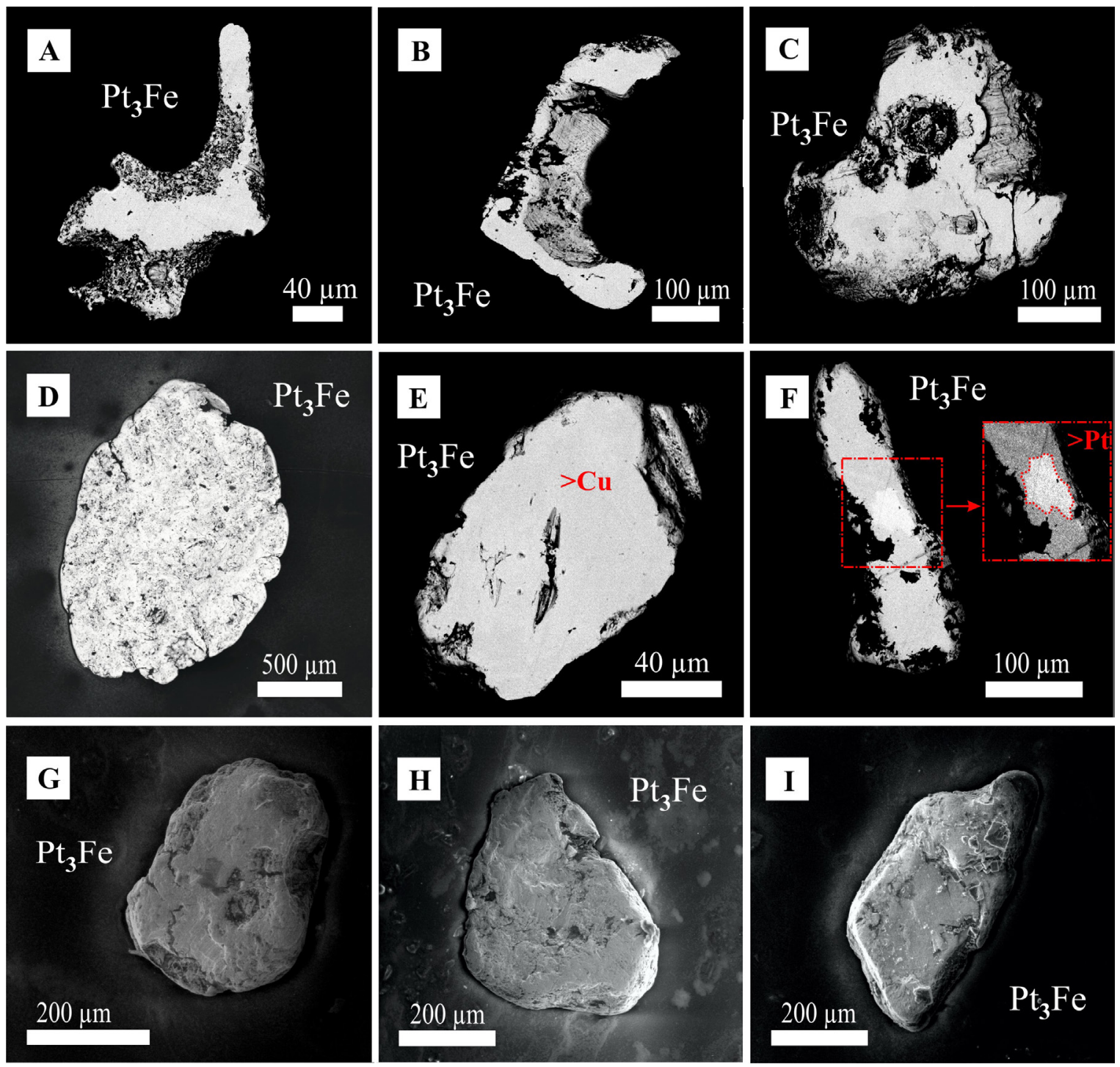

Figure 6 (A-F) Back-scattered electron (BSE) images and (G-I) Secondary electron (SE) images of characteristic grains of Pt-Fe alloy, E) Pt-Fe alloy with high $\mathrm{Cu}$ content (6.2 at. \%), F) Pt-Fe alloy with Pt-rich (bright) central part.

placer deposit as Weiser and Schmidt-Thomé (1993) found this mineral exclusively as an inclusion within Pt-Fe alloy. The grain shape is elongated and flat with porous texture (Figures 9C and 9D). The chemical composition of the grain is rather homogeneous with $\mathrm{Pt}$ ranging from 47.35 to 48.11 at. $\%$ and $\mathrm{Cu}$ ranging from 49.70 to 50.38 at. $\%$ (Table 5).

\subsubsection{INCLUSIONS OF CUPRORHODSITE IN Pt-Fe ALLOI}

Various small $(<3 \mu \mathrm{m}$ in diameter $)$ cuprorhodsite $\left(\mathrm{CuRh}_{2} \mathrm{~S}_{4}\right)$ inclusions were identified in a Pt-Fe alloy of approximately $80 \mu \mathrm{m}$ in diameter (Figure 10) by Raman spectroscopy (Figure 11). The inclusions, with anhedral to rounded shapes, show rather homogeneous chemical compositions with $\mathrm{Cu}$ varying from 5.65 to 12.28 at. $\%$, Rh from 9.97 to 18.61 at. $\%$, Pt from 10.74 to 31.96 at. $\%$, Ir from 0.47 to 0.78 at. $\%$, and S from 33.87 to 56.94 at. $\%$ (Table 6). The average composition in a.p.f.u. is $\left.\left[\mathrm{Cu}_{0,9}\left(\mathrm{Rh}_{1,3} \mathrm{Pt}_{0,8} \operatorname{Ir}_{0,0}\right)_{\sum 2,1} \mathrm{~S}_{4}\right)\right]$. Weiser and Schmidt-Thomé (1993) described similar cuprorhodsite inclusions crystallographically oriented within the Pt-Fe host. 
Table 1. Geochemical analyses for PGE and Au (ppm) of heavy mineral sample RS1.

\begin{tabular}{|c|c|c|c|c|c|c|c|c|}
$\begin{array}{c}\text { Panning } \\
\text { concentrate }\end{array}$ & $\mathrm{Au}$ & $\mathrm{Os}$ & $\mathrm{Ir}$ & $\mathrm{Ru}$ & $\mathrm{Rh}$ & $\mathrm{Pt}$ & $\mathrm{Pd}$ & $\Sigma$ PGE \\
\hline RS1 & 17.295 & 0.158 & 0.379 & 0.056 & 0.37 & 26.415 & 0.158 & 27.536 \\
\hline
\end{tabular}

Table 2. Overview of detected PGM and gold grains with respect to number and size fraction.

\begin{tabular}{c|c|c|c|c|c|c|c|c|}
\hline \multicolumn{2}{|c|}{} & $>1 \mathrm{~mm}$ & $630-500 \mu \mathrm{m}$ & $500-400 \mu \mathrm{m}$ & $400-355 \mu \mathrm{m}$ & $250-180 \mu \mathrm{m}$ & $125-75 \mu \mathrm{m}$ & $<30 \mu \mathrm{m}$ \\
\hline Number of & $\mathrm{PGM}$ & 1 & n.d. & 3 & 2 & 1 & 4 & 2 \\
grains & $\mathrm{Au}$ & n.d. & 3 & n.d. & n.d. & n.d. & n.d. & 8
\end{tabular}

Table 3. Chemical composition of Pt-Fe alloy (at. \%).

\begin{tabular}{|c|c|c|c|c|c|c|c|c|c|c|c|c|}
\hline Nr. & Os & Ir & $\mathrm{Ru}$ & $\mathrm{Rh}$ & $\mathrm{Pt}$ & $\mathrm{Pd}$ & $\mathrm{Fe}$ & $\mathrm{Cu}$ & $\mathrm{Ni}$ & $\mathrm{Co}$ & As & $\mathrm{S}$ \\
\hline 29 & bdl & 2.51 & 0.26 & 2.02 & 74.40 & 1.03 & 17.46 & 1.59 & 0.21 & 0.05 & 0.05 & 0.42 \\
\hline 24 & 0.17 & 2.33 & 0.65 & 2.26 & 74.00 & 1.15 & 17.47 & 1.48 & 0.04 & 0.10 & bdl & 0.35 \\
\hline 28 & 0.07 & 2.32 & 0.29 & 1.79 & 73.64 & 1.92 & 17.45 & 1.67 & 0.24 & 0.07 & bdl & 0.53 \\
\hline 32 & 0.19 & 2.16 & 0.46 & 1.90 & 74.38 & 1.29 & 17.44 & 1.61 & 0.11 & 0.10 & 0.08 & 0.28 \\
\hline 25 & 0.20 & 2.16 & 0.28 & 1.98 & 74.65 & 0.79 & 17.40 & 1.77 & 0.24 & 0.16 & bdl & 0.36 \\
\hline 27 & 0.13 & 2.13 & 0.33 & 2.25 & 73.75 & 2.19 & 17.19 & 1.45 & 0.21 & bdl & bdl & 0.36 \\
\hline 30 & bdl & 2.08 & 0.22 & 1.79 & 74.44 & 1.17 & 17.79 & 1.47 & 0.28 & 0.11 & bdl & 0.65 \\
\hline 20 & 0.81 & 4.09 & 0.04 & 2.70 & 70.32 & 0.94 & 18.12 & 2.28 & 0.31 & 0.00 & bdl & 0.39 \\
\hline 23 & 0.89 & 4.00 & 0.25 & 2.29 & 71.32 & 1.01 & 17.53 & 1.60 & 0.34 & 0.14 & bdl & 0.63 \\
\hline 21 & 0.82 & 3.91 & 0.34 & 2.52 & 65.87 & 1.51 & 17.99 & 6.21 & 0.43 & bdl & 0.07 & 0.32 \\
\hline 17 & 0.92 & 3.86 & 1.17 & 3.57 & 65.90 & 0.90 & 19.89 & 3.48 & 0.09 & bdl & bdl & 0.22 \\
\hline 15 & 0.79 & 3.55 & 0.72 & 2.45 & 65.70 & 1.44 & 19.29 & 5.20 & 0.37 & 0.03 & 0.09 & 0.38 \\
\hline 7 & 0.24 & 0.16 & 0.26 & 1.58 & 79.13 & 0.31 & 16.86 & 0.90 & 0.12 & 0.19 & bdl & 0.24 \\
\hline 8 & 0.14 & 0.26 & 0.08 & 2.34 & 77.05 & 2.04 & 16.37 & 1.04 & 0.31 & 0.01 & bdl & 0.35 \\
\hline 67 & 1.33 & 1.43 & 0.66 & 3.10 & 75.27 & 1.10 & 15.74 & 0.68 & 0.30 & bdl & bdl & 0.37 \\
\hline 12 & 0.19 & 0.36 & 0.27 & 2.33 & 77.61 & 1.17 & 16.34 & 0.98 & 0.25 & 0.15 & bdl & 0.36 \\
\hline 41 & 0.02 & 0.28 & bdl & 0.40 & 71.10 & 1.04 & 25.48 & 1.03 & 0.18 & 0.03 & 0.03 & 0.41 \\
\hline 40 & 0.02 & 0.32 & bdl & 1.36 & 71.55 & 0.52 & 24.95 & 0.89 & 0.01 & 0.01 & bdl & 0.37 \\
\hline 35 & 0.04 & 0.36 & 0.32 & 1.73 & 70.16 & 1.60 & 23.48 & 1.83 & 0.14 & 0.07 & bdl & 0.28 \\
\hline 34 & bdl & 0.28 & 0.18 & 2.20 & 70.31 & 1.53 & 23.45 & 1.80 & 0.03 & bdl & bdl & 0.22 \\
\hline 36 & 0.11 & 0.42 & bdl & 1.67 & 70.98 & 0.76 & 24.19 & 1.56 & 0.11 & 0.01 & bdl & 0.19 \\
\hline 37 & 0.04 & 0.36 & bdl & 2.13 & 70.76 & 0.63 & 24.87 & 1.01 & 0.03 & bdl & bdl & 0.16 \\
\hline 38 & bdl & 0.48 & 0.18 & 1.40 & 70.75 & 1.40 & 24.45 & 1.22 & bdl & 0.02 & bdl & 0.11 \\
\hline 39 & bdl & 0.28 & 0.19 & 1.11 & 71.79 & 0.45 & 24.78 & 0.90 & 0.22 & bdl & bdl & 0.27 \\
\hline 42 & bdl & 0.46 & bdl & 2.01 & 70.19 & 0.91 & 24.62 & 1.29 & 0.13 & 0.10 & bdl & 0.28 \\
\hline
\end{tabular}

bdl = below detection limit.

Table 4. Chemical composition of tulameenite (at. \%).

\begin{tabular}{|c|c|c|c|c|c|c|c|c|c|c|c|c|c|c|} 
Nr. & Os & Ir & Ru & Rh & Pt & Pd & Fe & Cu & Ni & Co & As & S \\
\hline 123 & 0.35 & 0.08 & 0.03 & 0.07 & 49.00 & bdl & 29.83 & 19.44 & 0.64 & 0.15 & bdl & 0.41 \\
124 & 0.32 & 0.39 & 0.24 & bdl & 48.27 & 0.74 & 29.46 & 19.28 & 0.75 & 0.21 & bdl & 0.33 \\
125 & 0.20 & 0.13 & 0.06 & 0.04 & 49.72 & bdl & 29.65 & 19.22 & 0.65 & 0.14 & bdl & 0.20 \\
122 & 0.32 & 0.01 & 0.12 & bdl & 48.46 & bdl & 30.50 & 19.01 & 0.67 & 0.23 & bdl & 0.69
\end{tabular}

bdl = below detection limit.

Table 5. Chemical composition of hongshiite (at. \%).

\begin{tabular}{|c|c|c|c|c|c|c|c|c|c|c|c|c|c|}
\hline Analysis & Os & $\mathrm{Ir}$ & $\mathrm{Ru}$ & $\mathrm{Rh}$ & $\mathrm{Pt}$ & $\mathrm{Pd}$ & $\mathrm{Fe}$ & $\mathrm{Cu}$ & $\mathrm{Ni}$ & $\mathrm{Co}$ & $\mathrm{As}$ & $\mathrm{S}$ \\
\hline 114 & 0.50 & 0.13 & $\mathrm{bdl}$ & $\mathrm{bdl}$ & 47.35 & $\mathrm{bdl}$ & 0.96 & 50.38 & 0.10 & 0.14 & bdl & 0.44 \\
115 & 0.69 & $\mathrm{bdl}$ & $\mathrm{bdl}$ & $\mathrm{bdl}$ & 47.92 & $\mathrm{bdl}$ & 0.75 & 50.36 & bdl & bdl & bdl & 0.29 \\
116 & 0.52 & $\mathrm{bdl}$ & $\mathrm{bdl}$ & $\mathrm{bdl}$ & 48.11 & $\mathrm{bdl}$ & 0.67 & 50.30 & bdl & bdl & 0.06 & 0.35 \\
117 & 0.82 & 0.04 & 0.02 & 0.01 & 47.56 & 0.24 & 0.52 & 50.29 & bdl & bdl & bdl & 0.50 \\
113 & 0.54 & bdl & 0.14 & bdl & 47.61 & bdl & 1.42 & 50.09 & bdl & bdl & bdl & 0.19 \\
118 & 0.69 & bdl & 0.04 & bdl & 47.72 & bdl & 1.03 & 50.07 & bdl & bdl & 0.01 & 0.44 \\
119 & 0.48 & 0.07 & 0.01 & bdl & 47.85 & bdl & 1.21 & 49.92 & bdl & 0.08 & bdl & 0.38 \\
121 & 0.74 & 0.03 & 0.27 & 0.07 & 47.53 & 0.31 & 0.84 & 49.71 & bdl & 0.02 & 0.04 & 0.45 \\
120 & 0.73 & bdl & bdl & bdl & 47.47 & 0.26 & 1.17 & 49.70 & 0.05 & bdl & 0.11 & 0.50
\end{tabular}

bdl = below detection limit. 
Table 6. Chemical composition of cuprorhodsite inclusions in Pt-Fe alloy (at. \%).

$\begin{array}{cccccccccccccccccc}\text { Nr. } & \text { Os } & \text { Ir } & \mathrm{Ru} & \mathrm{Rh} & \mathrm{Pt} & \mathrm{Pd} & \mathrm{Fe} & \mathrm{Cu} & \mathrm{Ni} & \mathrm{Co} & \mathrm{As} & \mathrm{S} & \text { notes } \\ 98 & 0.11 & 0.65 & 0.15 & 17.87 & 10.74 & \text { bdl } & 0.55 & 12.28 & 0.67 & 0.06 & \text { bdl } & 56.94 & \text { inclusion } \\ 103 & 0.21 & 0.68 & 0.40 & 15.60 & 13.52 & 0.12 & 0.99 & 12.20 & 0.50 & 0.05 & 0.01 & 55.72 & \text { inclusion } \\ 102 & 0.17 & 0.78 & \text { bdl } & 18.61 & 14.25 & 0.13 & 1.54 & 10.77 & 0.76 & 0.05 & \text { bdl } & 52.93 & \text { inclusion } \\ 101 & 0.30 & 0.47 & 0.97 & 11.54 & 29.41 & 0.31 & 5.44 & 8.59 & 0.56 & 0.05 & \text { bdl } & 42.37 & \text { inclusion } \\ 100 & 0.74 & 0.64 & 3.81 & 9.97 & 31.96 & 0.57 & 11.48 & 5.65 & 0.47 & 0.06 & 0.78 & 33.87 & \text { inclusion } \\ 88 & 0.36 & 0.37 & 0.55 & 1.47 & 71.72 & 1.01 & 16.52 & 6.30 & 0.72 & \text { bdl } & \text { bdl } & 0.97 & \text { host }\end{array}$

bdl = below detection limit.

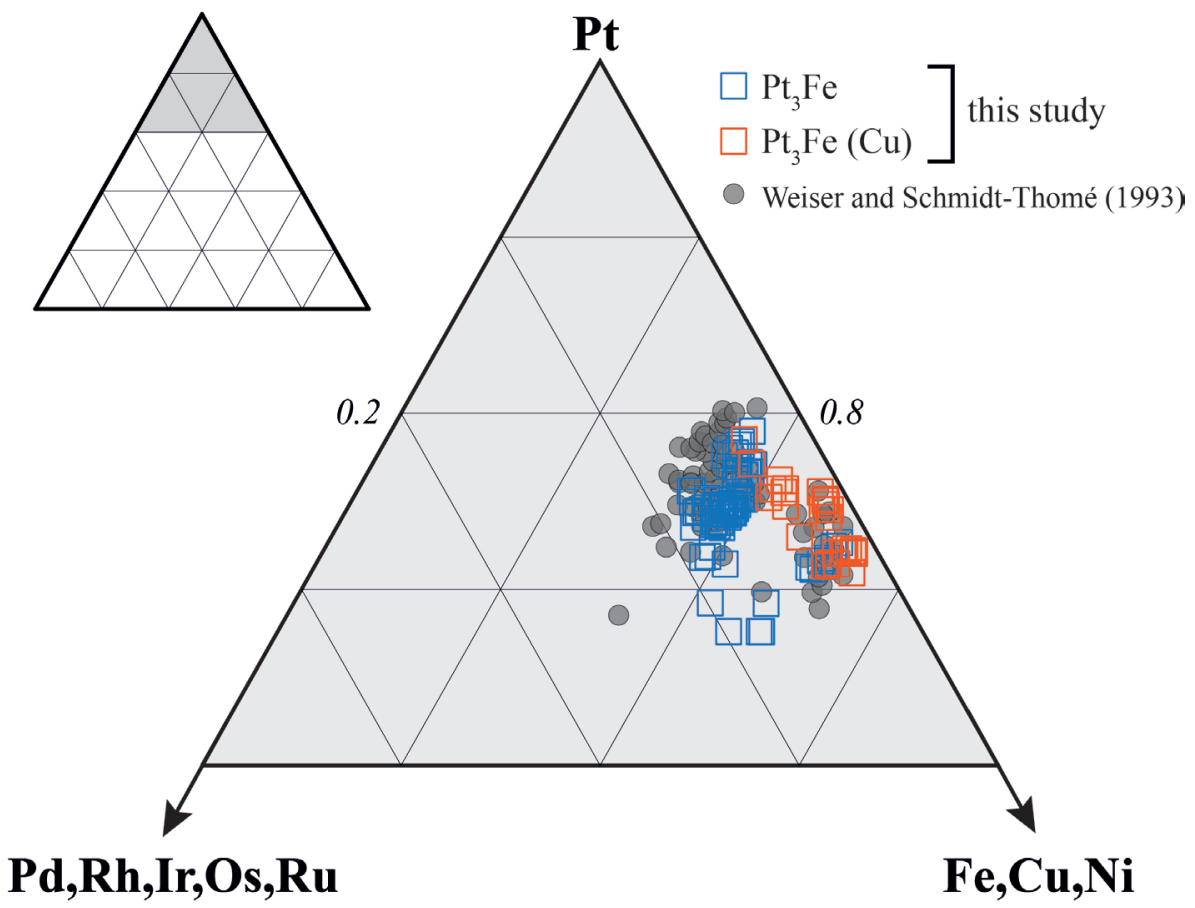

Figure 7 Pd, Rh, Ir, Os, Ru - Pt - Fe, Cu, Ni diagram showing the chemical composition of studied Pt - Fe alloys in comparison to Weiser and Schmidt-Thomé (1993).
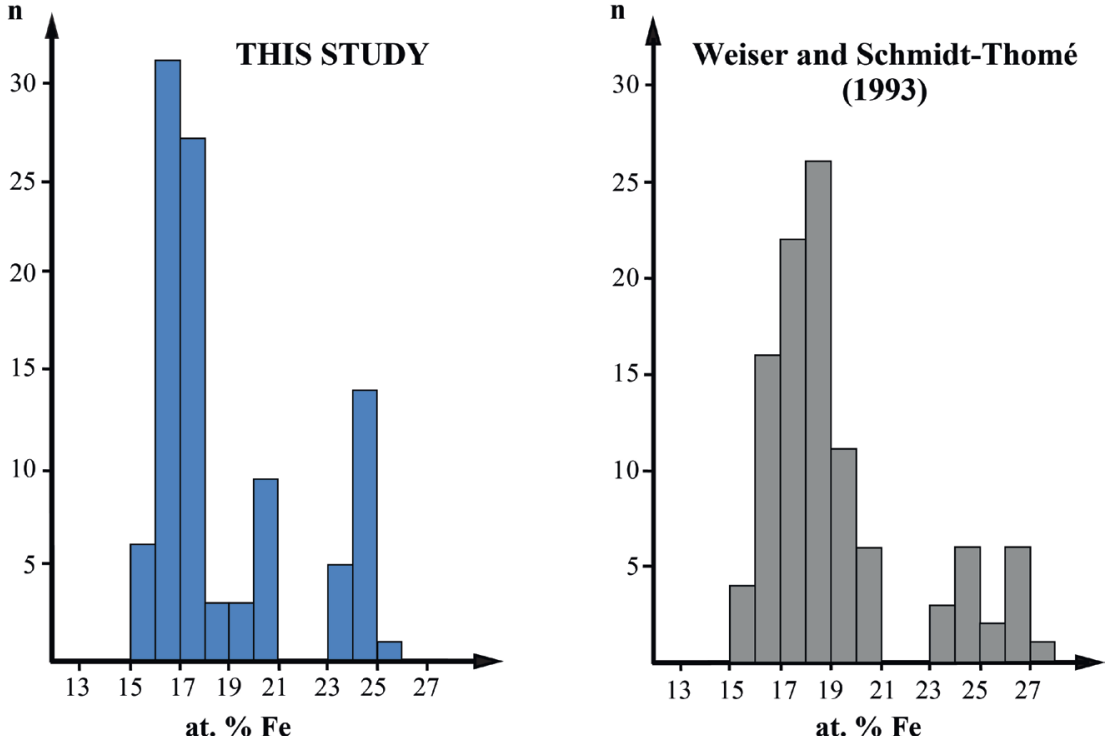

Figure 8 A) Frequency distribution of Fe (at. \%) in Pt-Fe alloy grains from the Río Santiago placer (this study; 7 points per grain), B) Frequency distribution of Fe (at. \%) in Pt-Fe alloy from the Río Santiago placer by Weiser and Schmidt-Thomé (1993) (single analysis per grain). 
(10) / Boletín de la Sociedad Geológica Mexicana / 72 (3) / A090720 / 2020
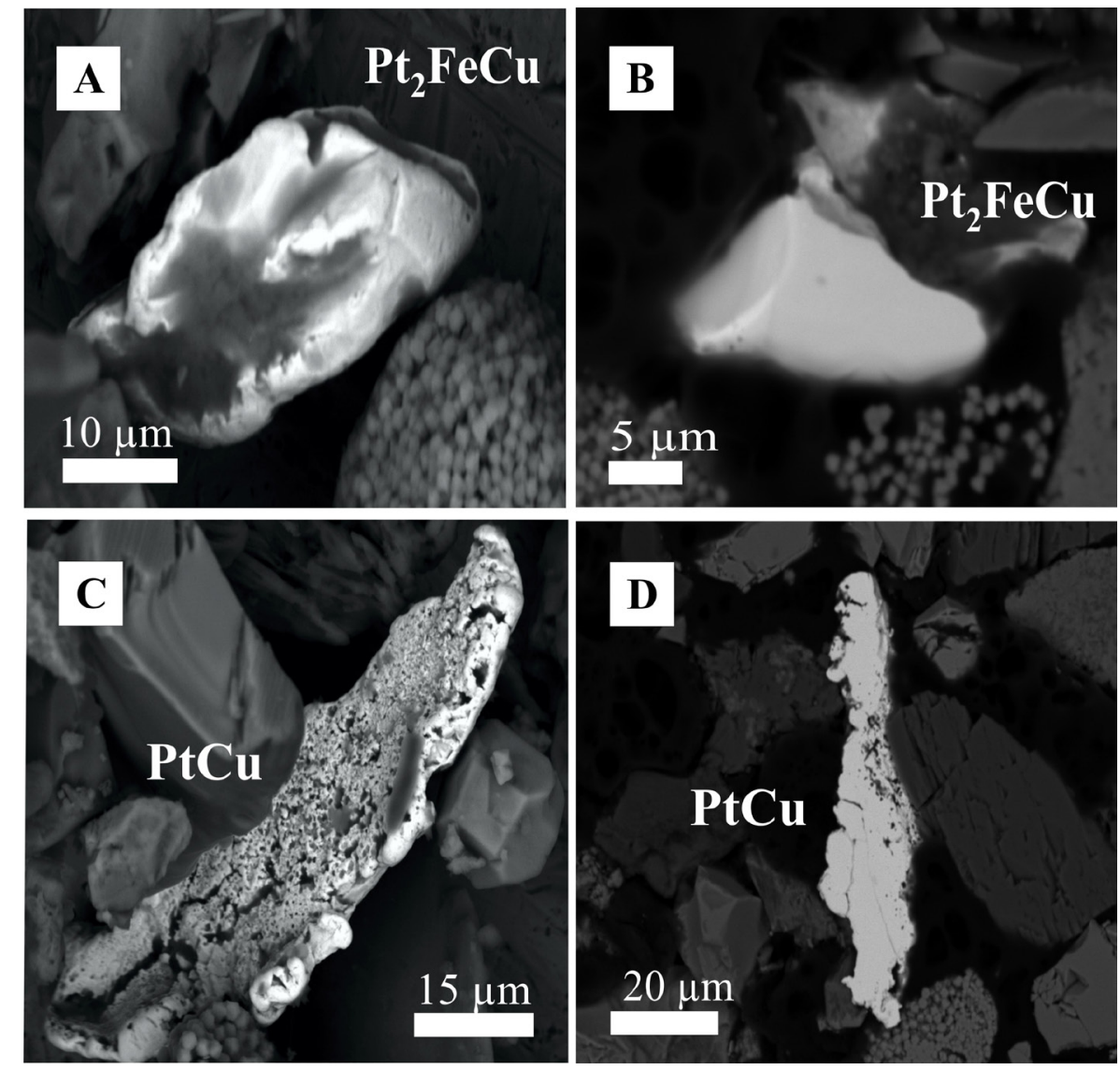

Figure 9 BSE images of unpolished and polished tulameenite (A and B) and hongshiite (C and D).
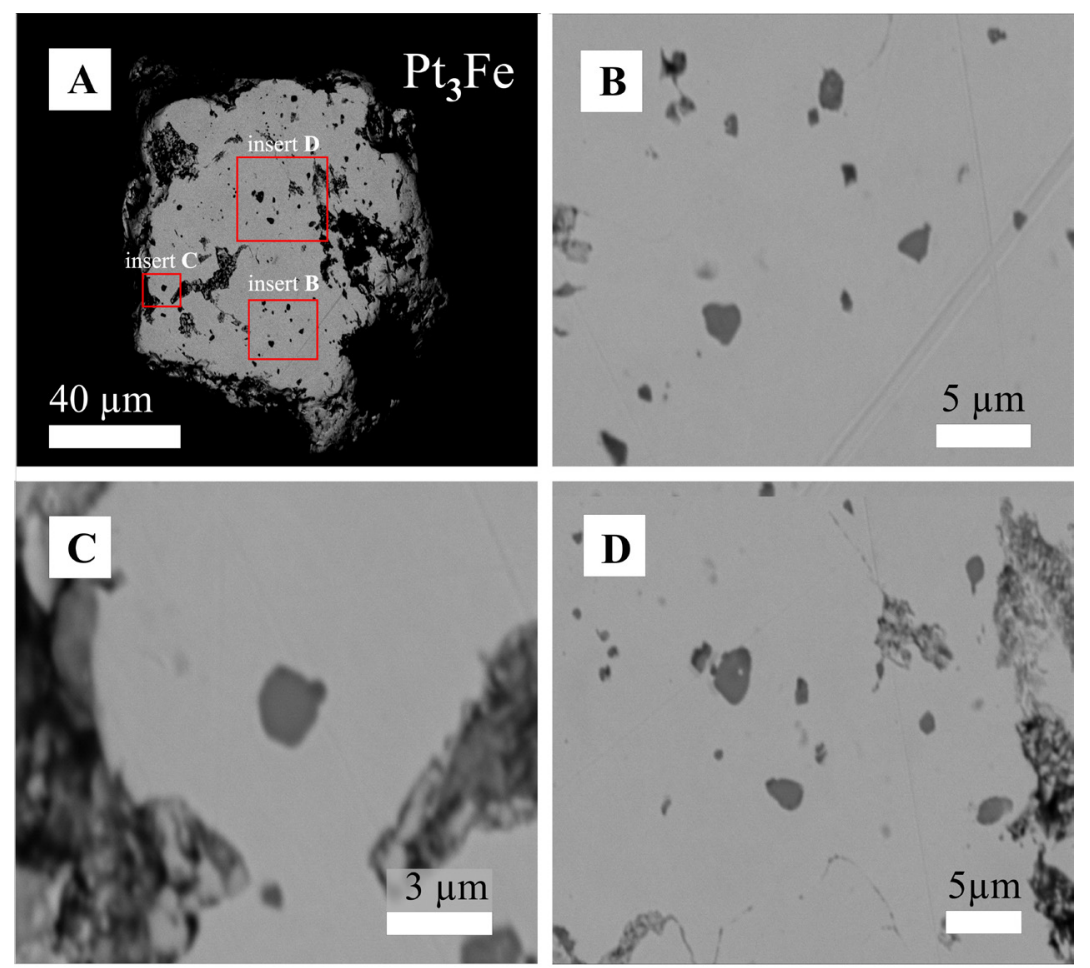

Figure 10 BSE images of an Pt-Fe alloy grain hosting numerous inclusions of cuprorhodsite. 


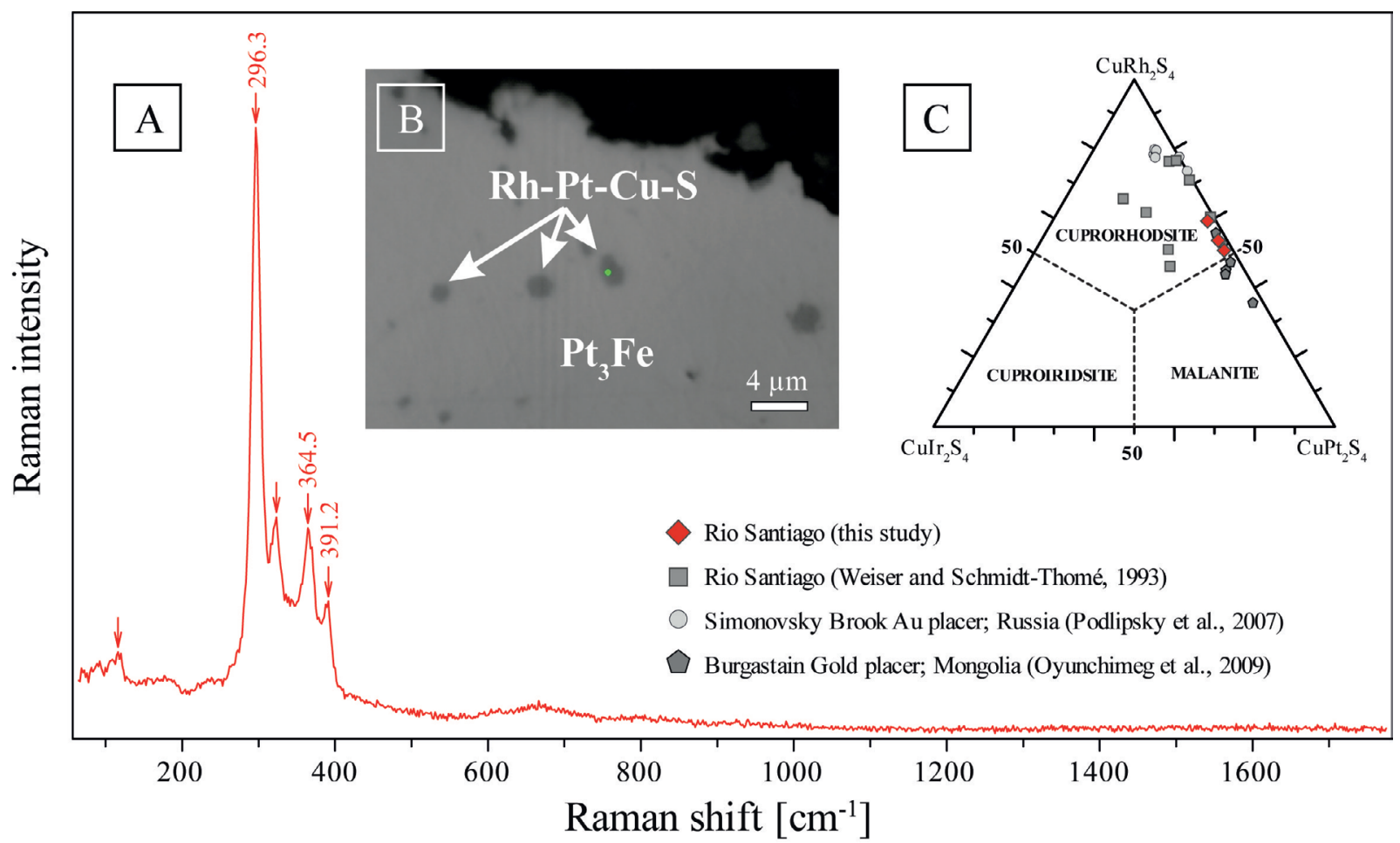

Figure 11 A) Raman spectrum of cuprorhodsite, B) Reflected light image showing cuprorhodsite inclusions in Pt-Fe alloy; the measuring point for the Raman spectrum is highlighted in green, C) Ternary diagram $\left(\mathrm{CuIr}_{2} \mathrm{~S}_{4}-\mathrm{CuRh}_{2} \mathrm{~S}_{4}-\mathrm{CuPt}_{2} \mathrm{~S}_{4}\right)$ showing the composition of cuprorhodsite of this study in comparison with data from Weiser and Schmidt-Thomé (1993), Podlipsky et al. (2007), and Oyunchimeg et al. (2009).

\section{Discussion}

\subsection{PGM IN THE RÍO SANTIAGO PLAGER}

Table 7 gives an overview of the PGM found in the Río Santiago placer deposit to date. The observed Pt-dominated PGE mineralogy correlates with the high total PGE content of 27.5 ppm in geochemical analyses of the panning concentrate (Table 1). The chondrite-normalized PGE pattern with positive anomalies for Pt and Ir is typical for worldwide Ural-Alaska type complexes (i.e. Nizhny-Tagil and Uktus in Urals, Tulameen in Canada, Condoto in Colombia; Garuti et al., 1997; Guillou-Frottier et al., 2014; O’Driscoll and González-Jiménez, 2016 and references therein; Figure 12).

The Río Santiago PGM assemblage is characterised by the Pt-Fe alloy-dominated PGE mineralogy (Table 1). Such a PGM assemblage has previously been related to chromitites from the dunitic core of Ural-Alaska type complexes (Nixon et al., 1990). The finest size fraction $(<30 \mu \mathrm{m})$ hosts the minerals tulameenite and hongshiite as individual, free grains. Tulameenite is considered a typical mineral for Ural-Alaska type complexes (Johan, 2002) and is believed to be formed due to fluid interaction after the reaction (Nixon et al., 1990):

$$
\mathrm{Pt}_{3} \mathrm{Fe}+2 \mathrm{Cu}=\mathrm{Pt}_{2} \mathrm{CuFe}+(\mathrm{Cu}, \mathrm{Pt})
$$

isoferroplatinum $+\mathrm{Cu}$ (in fluid) $=$ tulameenite + platinian copper (or hongshiite)

Hongshiite (or platinian copper) is related to low temperature hydrothermal activity (O'Driscoll and González-Jiménez, 2016) and the observed porous texture (Figures 9C and 9D) could indicate late stage copper leaching (Kwitko et al., 2002).

\subsection{PGM FORMATION}

The main PGE mineralization found in the Río Santiago alluvial placer is Pt-Fe alloy. However, this evidence alone is not enough to relate this deposit to a placer derived from the weathering of 
Table 7. Overview of PGM described in the Río Santiago placer deposit ( $G$ = free grain, I = inclusion).

\begin{tabular}{|c|c|c|c|}
\hline \multicolumn{2}{|c|}{ PGM decribed in Ecuador } & \multicolumn{2}{|r|}{ Studies } \\
\hline mineral & formula & present study & Weiser and Schmidt-Thomé (1993) \\
\hline Pt-Fe alloy & $(\mathrm{Pt}, \mathrm{Rh}, \mathrm{Ir})_{3}(\mathrm{Fe}, \mathrm{Cu})$ & G & G \\
\hline tulameenite & $\mathrm{CuFePt}_{2}$ & G & \\
\hline hongshiite & $\mathrm{PtCu}$ & G & I \\
\hline cuprorhodsite & $\mathrm{CuRh}_{2} \mathrm{~S}_{4}$ & I & I \\
\hline cooperite & $\mathrm{PtS}$ & & I \\
\hline bowieite & $\mathrm{Rh}_{2} \mathrm{~S}_{3}$ & & I \\
\hline erlichmanite & $\mathrm{OsS}_{2}$ & & I \\
\hline laurite & $\mathrm{RuS}_{2}$ & & I \\
\hline braggite & $(\mathrm{Pt}, \mathrm{Pd}, \mathrm{Ni}) \mathrm{S}$ & & I \\
\hline sperrylite & $\mathrm{PtAs}_{2}$ & & I \\
\hline osmium & Os (+ Ru and Ir) & & $\mathrm{I}$ \\
\hline PGM unnamed & $(\mathrm{Pt}, \mathrm{Pd})_{3}(\mathrm{As}, \mathrm{Sb}, \mathrm{Te}) \mathrm{Pt}_{12} \mathrm{Cu}_{8} \mathrm{~S}_{5}$ & & I \\
\hline
\end{tabular}

an Ural-Alaska type complex as placers related to ophiolitic ultramafic complexes can also contain significant amounts of Pt-Fe alloys (Tolstykh et al., 2005).

Compositional variations of PGE in Pt-Fe alloy from our study reveal elevated contents of Ir and Rh (Figure 13). Slansky et al. (1991) linked the chemical diversity of Pt-Fe alloy to primary sources and different ore deposit and temperatures. Following their approach, the origin of Pt-Fe alloy from the Río Santiago alluvial placer could be related to (weathered) chromitites from a dunite core. A strong argument against this theory is, however, that chromite is not an abundant mineral phase in the study area according to XRD analyses.

The study of the mineral paragenesis and the evolution of the ore forming system can be used as criteria to relate the PGE-bearing placers either to Ural-Alaska type complexes or to ophiolitic ultramafic complexes. Tolstykh et al. (2005) suggest that in a silicate melt containing PGE, Os would crystallize before olivine. Hence, olivine crystallization would trigger an increase of oxygen fugacity $\left(f \mathrm{O}_{2}\right)$, lowering the solubility of $\mathrm{Pt}$ and $\mathrm{Ir}$ and inhibiting the formation of Ru-, Rh- and Pdbearing PGM (Tistl, 1994). The system progresses with an increase of $f \mathrm{O}_{2}$ and sulphur fugacity $\left(f \mathrm{~S}_{2}\right)$, therefore allowing an increase in Ir concentration. The magmatic process ends with the crystallization of $\mathrm{Pt}-\mathrm{Fe}$ alloys that are rich in $\mathrm{Pd}, \mathrm{Rh}$ and $\mathrm{Cu}$ in the interstices of the chromite grain (Tolstykh et al., 2005). This scenario explains well the general observation that $\mathrm{Os}-\mathrm{Ir}-\mathrm{Ru}$ alloys typically occur in Ural-Alaska type complexes as inclusions within $\mathrm{Pt}-\mathrm{Fe}$ alloys. However, and in contrast to Weiser and Schmidt-Thomé (1993; total of 103 PGM found), no $\mathrm{Os}-\mathrm{Ir}-\mathrm{Ru}$ alloys were discovered in the present study (total of 13 PGM found).

\subsection{POTENTIAL PROVENANGE}

Weiser and Schmidt-Thomé (1993) suggested that the Macuchi Formation could be a possible source rock provided that the PGM of Río Santiago were weathered from an ophiolite complex. 


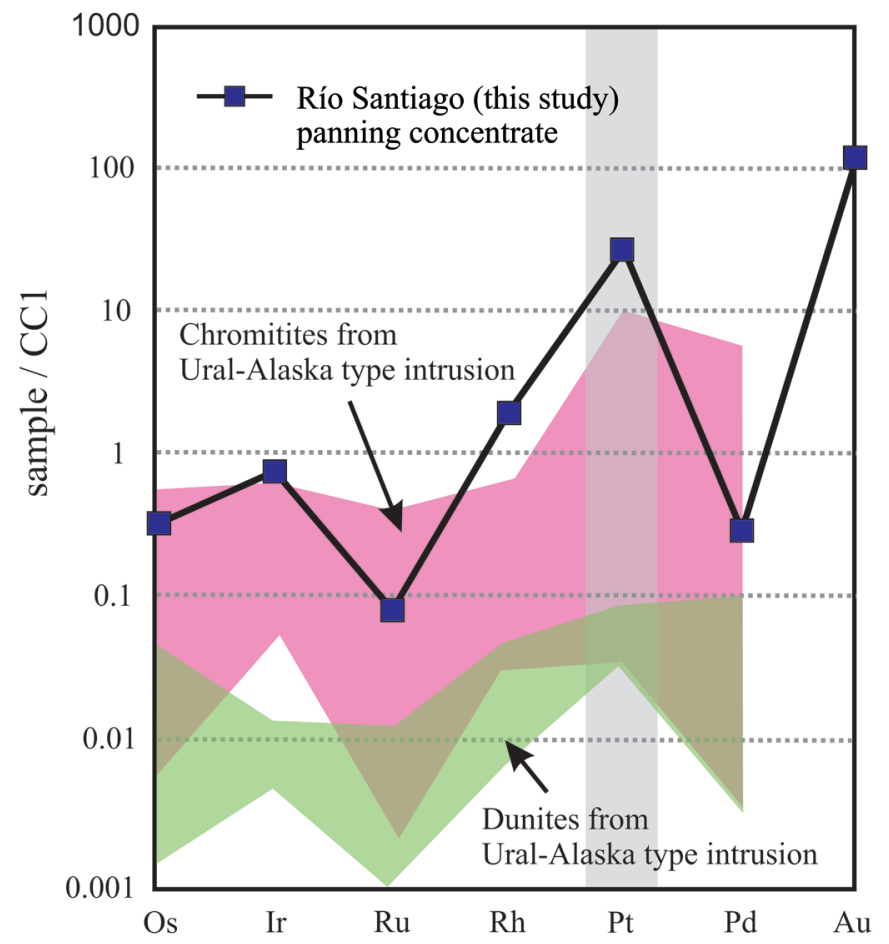

Figure 12 Comparison between the chondrite-normalized PGE pattern from the Río Santiago (this study) and the shape of chondritenormalized patterns of chromitites and dunites associated with Ural-Alaska type intrusions around the world (modified from O'Driscoll and González-Jiménez, 2016).

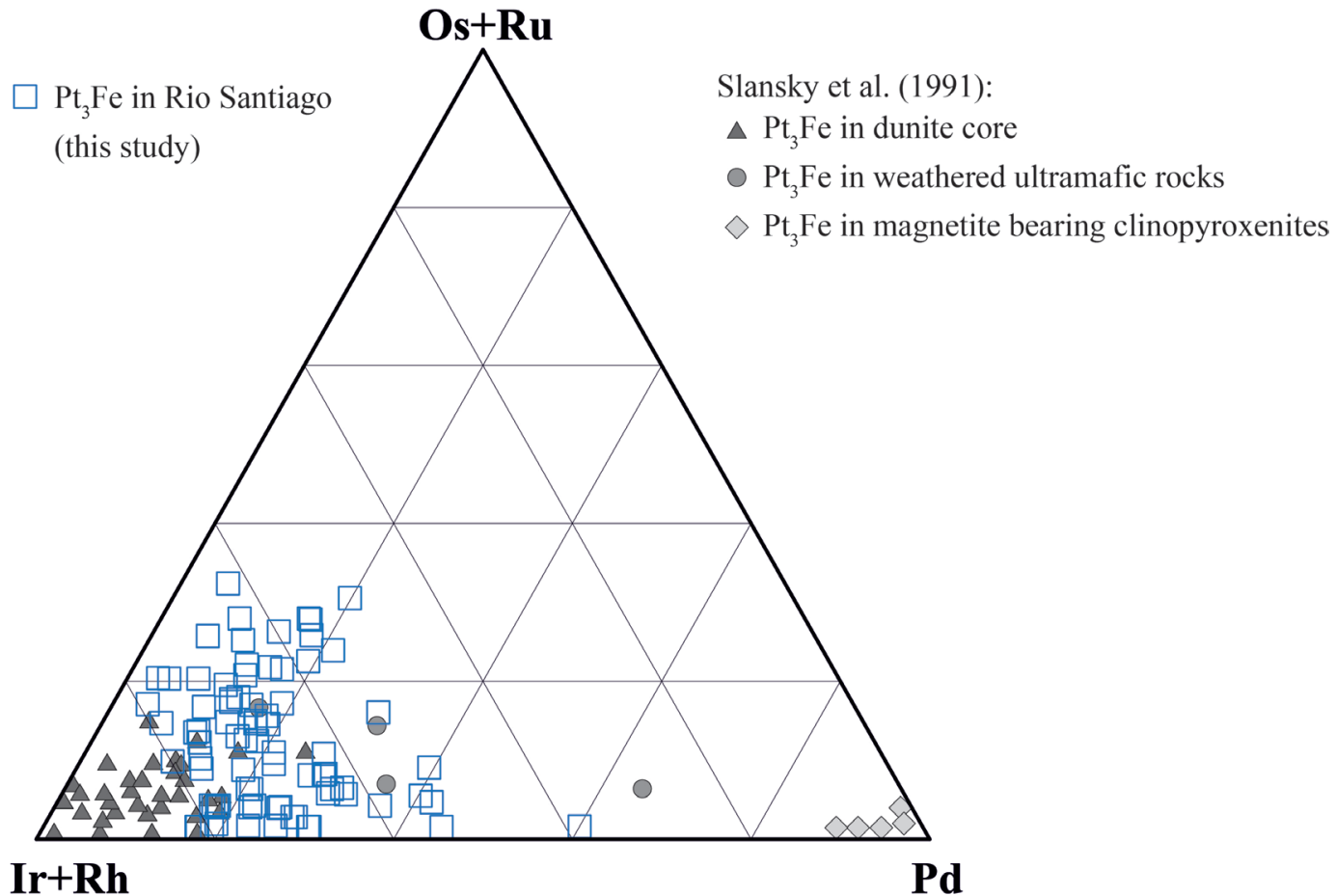

Figure $13 \mathrm{Ir}, \mathrm{Rh}$ - Os, Ru - Pd ternary plot showing the chemical composition of Pt - Fe alloys detected in this study in comparison with data from Slansky et al. (1991). 
On the other hand, if the PGM derived from an Ural-Alaska type complex then the source would be unknown. Weiser and Schmidt-Thomé (1993) preferred this second option and the new data provided in the present study also suggest that the PGM from the Río Santiago alluvial placer deposit originated from the weathering of an unknown mafic-ultramafic Ural-Alaska type complex.

The occurrence of mafic-ultramafic rocks has been described by Vallejo (2007) and Mamberti et al. (2004) in the Western Cordillera, namely the San Juan and Pallatanga formations. The San Juan Fm. consists of mafic and ultramafic rocks with massive dunite at the base, grading upwards through layered wehrlites and gabbros into isotropic amphibole gabbros (Mamberti et al., 2004). This formation shows petrological characteristics for an Ural-Alaska type complex that not necessarily have to be associated with subduction nor have to appear exclusively as concentric intrusions (Guillou-Frottier et al., 2014). A plume model was introduced by Sutherland (1998) in which magmatic diapirs derived from the plume head can create "tube-like" intrusions in zones of increasing tensional stress. Based on lithological associations, geodynamic setting, magma composition, mineral assemblages, isotopic and trace element composition, Mamberti et al. (2004) interpreted that the San Juan Fm. represents a plutonic component inside an oceanic plateau setting (Late Cretaceous Caribbean Colombia Oceanic Plateau, CCOP). On the other hand, Cosma et al. (1998) interpreted the San Juan Fm. as a part of a mafic - ultramafic root zone from an oceanic plateau sequence. Vallejo (2007) suggested that Piñón, San Juan and Pallatanga Fms. represent accreted oceanic fragments of the same large igneous province (LIP), which were accreted to the South American Plate during the Late Cretaceous.

Another hypothesis was a common origin for the PGM found in the Río Santiago alluvial placer and the Alto Condoto placer (Colombia). This has been suggested due to their similar mineralogical associations but Weiser and Schmidt-Thomé (1993) highlighted the low concentrations of Ru in the Río Santiago nuggets compared with nuggets from Colombia (Toma and Murphy, 1977). In addition to mineralogical evidence (Gervilla et al., 2020), the possibility that PGM from Río Santiago originated from Alto Condoto is not likely from a geographic point of view. As shown in Figure 2A, Río Santiago originates at the Western Cordillera in Ecuador without any geographical or hydrological connection to the Alto Condoto Complex in Colombia. Furthermore, the difference in the geodynamic setting, as well as in age of the intrusions, gives additional concerns. The Ultramafic Alto Condoto Complex is known as the youngest zoned Ural-Alaska complex in the world (20 \pm 1 $\mathrm{Ma})$ related to primitive oceanic arc islands (Tistl et al., 1994), whereas the mafic - ultramafic rocks from the San Juan Formation were dated by $\mathrm{U}-$ $\mathrm{Pb}$ on zircon, giving an age of $87.1 \pm 1.66 \mathrm{Ma}$ (Vallejo, 2007). Furthermore, ${ }^{40} \mathrm{Ar} /{ }^{39} \mathrm{Ar}$ studies in amphiboles from the same formation gave an age of $99.2 \pm 1.3 \mathrm{Ma}$ (Mamberti et al., 2004).

Ural-Alaska type complexes are usually related to either mobile belts (i.e. Urals, Alaska, British Columbia, Kamchatka, Colombia) or to geodynamic stable platforms (i.e. Aldan, Ethiopia, Russia; Guillou- Frottier et al., 2014). Nevertheless, based on lithological association and mineralogy, the described PGM from the Río Santiago alluvial placer do not fit in any of these geological environments. There is an absence of evolved calc-alkaline suites and the presence of basalts with flat chondrite-normalized REE patterns together with $\mathrm{Zr}$ and $\mathrm{Nb}$ anomalies in clinopyroxene and in host peridotites, suggests that the San Juan Fm. represents the plutonic component of an oceanic plateau (Mamberti et al., 2004). Sutherland (1998) and Gerya and Burg (2007) proposed a plume model, where ultramafic bodies derived from a plume head could rise through the lithospheric mantle and the crust due to local rheological properties by means of a mechanism called "translithospheric diapirism". Following this model, PGM from the Río Santiago alluvial placer could be derived from Ural-Alaska type ultramafic intrusions connected to a mantle plume (oceanic plateau). If this hypothesis is correct, Río Santiago would represent the first occurrence of PGE-bear- 
ing placers derived from Ural-Alaska type related to an oceanic plateau formed by decompression melting of hot mantle plumes.

Alternatively, an Alaska-Ural complex could also have formed during the formation of the Upper Cretaceous arc, "growing" on the plateau. Evidence for these are the Río Cala and Naranjal units with tholeiitic and calc-alkaline affinities, which crop out in the Río Santiago area (Villares-Jibaja, personal communication, July 22, 2020). In addition, Chulde (2017) recently reported mafic bodies (hornblendic gabbros) in northwestern Ecuador, and in the coastal region, Macias-Mosquera and Rojas-Agramonte (2019) identified acidic intrusions related with subduction crosscutting the plateau, with ages between 98 and $86 \mathrm{Ma}$.

\section{Conclusions and ideas for future research}

This contribution aims to reawaken the reader's attention to the PGM (and $\mathrm{Au}$ ) found in the Río Santiago in Ecuador with the still open questions of provenance and geological history of the alluvial noble metal concentration. Based on the results of the present study the following conclusions can be drawn:

- One heavy mineral concentrate sample from the Río Santiago placer showed high contents of PGE (27.5 ppm) and Au (17.3 ppm). Chondrite-normalized PGE patterns revealed a characteristic " $\mathrm{M}$ " shape with negative $\mathrm{Ru}$ and $\mathrm{Pd}$ but positive $\mathrm{Ir}$ and Pt anomalies, typical for Ural-Alaska type complexes.

- The main PGM from the Río Santiago alluvial placer is $\mathrm{Pt}-\mathrm{Fe}$ alloy $(85 \%$ of the grains) with elevated contents of Ir and Rh. Tulameenite and hongshiite were found as free grains in the finest fraction $(<30 \mu \mathrm{m})$ and cuprorhodsite inclusions $(<3$ $\mu \mathrm{m})$ were identified within a Pt-Fe alloy grain.
- The primary source of the PGE mineralization in the Río Santiago alluvial placer remains unknown and has maybe been eroded away. However, one option that should be investigated in the future is the possibility that the PGE mineralization is related to mafic - ultramafic bodies that have been described in the mafic basement of the coastal region and the Western Cordillera, which are derived from the Late Cretaceous Caribbean Colombia Oceanic Plateau (CCOP).

- In case the PGE mineralization from the Río Santiago alluvial placer originates from the Cretaceous large igneous province it would represent the first occurrence of a PGM-bearing placer deposit related to Ural-Alaska type complexes within an oceanic plateau.

\section{Acknowledgements}

This research has been financially supported by the projects CGL2012-36263 and PID2019105625RB-C21 of the Spanish Ministry of Science and Innovation and the Caribbean Lithosphere Research Group (http://caribbeanlithos. ub.edu). We thank Thomas Oberthür, Malte Junge and an anonymous reviewer for their constructive criticisms, which improved our manuscript.

\section{References}

Aiglsperger, T., Proenza, J.A., Zaccarini, F. Lewis, J.F., Garuti, G., Labrador, M., Longo, F., 2015, Platinum group minerals (PGM) in the Falcondo Ni-laterite deposit, Loma Caribe peridotite (Dominican Republic): Mineralium Deposita, 50, 105-123. https:// doi.org/10.1007/s00126-014-0520-9

Aspden, J.A., Litherland, M., 1992, The geology and Mesozoic collisional history of the Cordillera Real, Ecuador, in Oliver, 
R.A., et al. (eds.), Andean Geodynamics: Tectonophysics, 205, 187-204. https://doi. org/10.1016/0040-1951(92)90426-7

Cabri, L.J., Harris, D.G., Weiser, T.W., 1996, Mineralogy and distribution of platinumgroup mineral (PGM) placer deposits of the world: Exploration and Mining Geology, 5, 73-167.

Cabri, L.J., Owens, D.R., Laflamme, L.H.G., 1973, Tulameenite, a new platinum-ironcopper mineral from placers in the Tulameen River area, British Columbia: Canadian Mineralogist, 12, 21-25.

Chulde, E., 2017, Caracterización petrográfica, geoquímica y petrogenética de los gabros hornbéndicos expuestos en la Carolina (Guallupe). Implicaciones regionales en la configuración de la Cordillera Occidental Septentrional del Ecuador: Quito, Escuela Politécnica Nacional, Master dissertation.

Cosma, L., Lapierre, H., Jaillard, E., Laubacher, G., Bosch, D., Desmet, A., Mamberti, M., Gabriele, P., 1998, Pétrographie et géochimie des unités magmatiques de la Cordillère occidentale d'Équateur (0B30VS) :implications tectoniques : Bulletin Société Géologique de France, 169, 739- 751.

Garuti, G., Fershtater, G., Bea, F., Monterao, P., Pushkarev, E.V., Zaccarini, F., 1997,Platinumgroup elements as petrological indicators in mafic-ultramafic complexes of the central and southern Urals: preliminary results: Tectonophysics, 276, 181-194. https://doi. org/10.1016/s0040-1951(97)00050-4

Gervilla, F., Proenza, J.A., Frei, R., GonzálezJiménez, J.M., Garrido, C.J., Melgarejo, J.C., Meibom, A., Díaz-Martínez, R., Lavaut, W., 2005, Distribution of platinumgroup elements and Os isotopes in chromite ores from Mayarí-Baracoa Ophiolitic Belt (eastern Cuba): Contributions to Mineralogy and Petrology, 150, 589-607. https://doi. org/10.1007/s00410-005-0039-2

Gervilla F., García-Guinea J., Capitán-Vallvey L.F., 2020, Platina in the 18th century:
Mineralogy of the crude concentrate used in the first modern attempts at refining platinum: Mineralogical Magazine, 84, 289299. https://doi.org/10.1180/mgm.2020.3

Gerya, T.V., Burg,J.P., 2007, Intrusion of ultramafic magmatic bodies into the continental crust: numerical simulation: Physics of the Earth and Planetary Interiors, 160, 124-142. https://doi.org/10.1016/j.pepi.2006.10.004 Guillou-Frottier, L., Burov, E., Augé, T., Gloaguen, E., 2014, Rheological conditions for emplacement of Ural-Alaskan-type ultramafic complexes: Tectonophysics, 631, 130-145. https://doi.org/10.1016/j. tecto.2014.02.002

Instituto Nacional de Investigaciones Geológico, Minero y Metalúrgicas (INIGEMM), Ministerio de Energía y Minas, 2001, Hoja Geológica Esmeraldas y Galera (1:100.000): INIGEMM, Ecuador.

Johan, Z., 2002, Alaskan-type Complexes and their platinum-group element mineralization, in Carbi, L.J. (ed.), The Geology, Geochemistry, Mineralogy and Mineral beneficiation of platinum-group elements: Montreal, Canadian Institute of Mining, Metallurgy and Petroleum, 54, $852 \mathrm{p}$.

Juan J., Ulloa A., 1748, Relación Histórica del Viage a la América Meridional hecho de orden de S. Mag. Para medir algunos grados de meridiano terrestre: Madrid, A. Marín, Vol. I, 606 p.

Kerr, A.C., Aspden, J.A., Tarney, J., Pilatasig, L.F., 2002, The nature and provenance of accreted oceanic terranes in western Ecuador: geochemical and tectonic constraints: Journal of the Geological Society, 159, 577-594. https://doi.org/10.1144/0016-764901-151

Knight, J.B., Morison, S.R., Mortensen, J.K., 1999, The Relationship between Placer Gold Particle shape, rimming and distance of fluvial transport as exemplified by Gold from the Klondike District, Yukon Territory, Canada: Economic Geology, 94, 635-648. https:// doi.org/10.2113/gsecongeo.94.5.635 
Krause, J., 2008, Petrogenetic evolution of UralianAlaskan -type mafic-ultramafic complexes in the southern and middle Urals, Russia: Mainz, Johannes Gutenberg-Universität, $\mathrm{PhD}$. dissertation.

Kwitko, R., Cabral, A.R., Lehmann, B., Laflamme, J.G., Cabri, L.J., Criddle, A.J., Galbiatti, H.F., 2002, Hongshiite, PtCu, from itabirite-hosted $\mathrm{Au}-\mathrm{Pd}-\mathrm{Pt}$ mineralization (jacutinga), Itabira district, Minas Gerais, Brazil: The Canadian Mineralogist, 40, 711-723. https://doi. org/10.2113/gscanmin.40.2.711

Luzieux, L.D.A., Heller, F., Spikings, R., Vallejo, D.F., Winkler, W., 2006, Origin and Cretaceous tectonic history of the coastal Ecuadorian forearc between $1^{\circ} \mathrm{N}$ and $3^{\circ} \mathrm{S}$ : Paleomagnetic, radiometric and fossil evidence: Earth and Planetary Science Letters, 249, 400-414. https://doi. org/10.1016/j.epsl.2006.07.008

Macias-Mosquera, K.S., Rojas-Agramonte, Y., 2019, Age, geochemistry and emplacement of the Pascuales plutons in western Ecuador and their geodynamic implications, in 8th International Symposium on Andean Geodynamics, 2019: Quito, Ecuador. https://www.igepn.edu.ec/8isag-abstracts/ magmatism/22768-macias-mosquera-etal/file

Mamberti, M., Lapierre, H., Bosch, D., Jaillard, E., Hernandez, Polve, M., 2004, The Early Cretaceous San Juan Plutonic Suite, Ecuador: a magma chamber in an oceanic plateau?: Canadian Journal of Earth Sciences, 41, 1237-1258. https://doi.org/10.1139/ e04-060

Martin-Gombojav, N., Winkler, W., 2008, Recycling of Proterozoic crust in the Andean Amazon foreland of Ecuador: Implications for orogenic development of the Northern Andes: Terra Nova, 20, 22-31. https://doi. org/10.1111/j.1365-3121.2007.00782.x

Mertie, J., 1969, Economic Geology of the Platinum Metals: U.S. Geological Survey Prof. Paper 630, 120 pp. https://doi. org/10.3133/pp630
Naldrett, A. J., Duke J.M., 1980, Platinum metals in magmatic sulfide ores: Science, 208, 1417-1428. https://doi.org/10.1126/ science.208.4451.1417

Nixon, G.T., Cabri, L.J., Laflamme J.H.G., 1990, Platinum -group-element mineralization in lode and placer deposits associated with the Tulameen Alaskan -Type Complex, British Columbia: Canadian Mineralogist, 28, 503-535.

O’Driscoll, B., González-Jiménez M., 2016, Petrogenesis of the Platinum-Group Minerals: Reviews in Mineralogy and Geochemistry, 81, 489-578. https://doi. org/10.1515/9781501502095-011

Oyunchimeg, T., Izokh, A.E., Vishnevsky, A.V., Kalugin, V.M., 2009, Isoferroplatinum mineral assemblage from the Burgastain Gol placer (Western Mongolia): Russian Geology and Geophysics, 50, 863-872. https://doi. org/10.1016/j.rgg.2009.09.004

Podlipsky, M.Y., Nesterenko, G.V., Krivenko, A.P., 2007, Isoferroplatinum mineral assemblage in the northwestern Salair gold placer: Russian Geology and Geophysics, 48, 291-298. https://doi.org/10.1016/j.rgg.2005.11.001

Reyes, P., Michaud, F., 2012, Mapa Geológico de la Margen Costera Ecuatoriana (1:500000): EP PetroEcuador -IRD (ed.), Quito, Ecuador. Slansky, E., Johan, Z., Ohnenstetter, M., Barron, L.M., Suppel, D., 1991, Platinum mineralization in the Alaskan-type intrusive complexes near Fifield, N.S.W., Australia. Part 2. Platinum-Group Minerals in placer deposits at Fifield: Mineralogy and Petrology, 43, 161-180. https://doi.org/10.1007/ bf01166889

Spikings, R.A. Winkler, W., Seward, D., Handler, R. 2001, Along-strike variations in the thermal and tectonic response of the continental Ecuadorian Andes to the collision with heterogeneous oceanic crust: Earth and Planetary Science Letters, v. 186, p. 57-73. https://doi.org/10.1016/ S0012-821X(01)00225-4 
Sutherland, F.L., 1998, Origin of north Queensland Cenozoic volcanism: relationships to long lava flow basaltic field: Australian Journal of Scientific Research, 103, 27347-27358. https://doi.org/10.1029/97jb03578

Tistl, M., 1994, Geochemistry of Platinum-Group Elements of the Zoned Ultramafic Alto Condoto Complex, Northwest Colombia: Economic Geology, 89, 158-167. https:// doi.org/10.2113/gsecongeo.89.1.158

Tolstykh, N.D., Foley, J.Y., Sidorov, E.G., Laajoki K.O., 2002, Composition of the platinumgroup minerals in the Salmon Riven placer deposit, Goodnews Bay, Alaska: The Canadian Mineralogist, 40, 463-471.https:// doi.org/10.2113/gscanmin.40.2.463

Tolstykh, N.D., Sidorov, E.G., Krivenko, A.P., 2005, Platinum-group element placers associated with Ural-Alaska type complexes, in Mungall, J.E. (ed), Exploration for Platinum-Group Element Deposits: Mineralogical Association of Canada Short Course 35, 113-143.

Toma, S.A., Murphy, S., 1977, The composition and properties of some native platinum concentrates from different localities: The Canadian Mineralogist, 15, 59-69.

Vallejo, C., 2007, Evolution of the Western
Cordillera in the Andes of Ecuador (Late Cretaceous-Paleogene): Zürich, Institute of Geology, ETH Zürich, Ph.D. dissertation. https://www.research-collection.ethz.ch/ handle/20.500.11850/150007

Vallejo, C., Winkler, W., Spikings, R., Luzieux, L., Heller, F., Bussy, F., 2009, Mode and timing of terrane accretion in the forearc of the Andes in Ecuador, in Kay, S.M., Ramos, V.A., and Dickinson, W.R., (eds.), Backbone of the Americas: Shallow Subduction, Plateau Uplift, and Ridge and Terrane Collision: Geological Society of America Memoir 204, p. 197-216. https://doi. org/10.1130/2009.1204(09)

Weiser, T., Schmidt-Thomé, M., 1993, PlatinumGroup minerals from the Santiago River, Esmeraldas province, Ecuador: The Canadian Mineralogist, 31, 66-73.

Winkler, W., Villagómez, D., Spikings, R., Abegglen, P., Tobler, St., Egüez, A., 2005, The Chota basin and its significance for the inception and tectonic setting of the Inter-Andean Depression in Ecuador: Journal of South American Earth Sciences, 19, 5-19. https://doi.org/10.1016/j. jsames.2004.06.006 